International Journal of Social Sciences and Humanities
Available online at http://sciencescholar.us/journal/index.php/ijssh
Vol. 3 No. 1, April 2019, pages: $171 \sim 178$
e-ISSN: 2550-7001, p-ISSN: $2550-701 \mathrm{X}$
https://doi.org/10.29332/ijssh.v3n1.262

\title{
The Intensity of Stock Selection: A Case of Young Papuan Investors
}

\author{
Yohanes C. Seralurin ${ }^{a}$, Yendra ${ }^{b}$ \\ Article history: Received 18 August 2018, Accepted: 31 December 2018, Published: 25 April 2019
}

\section{Correspondence Author ${ }^{\text {a }}$}

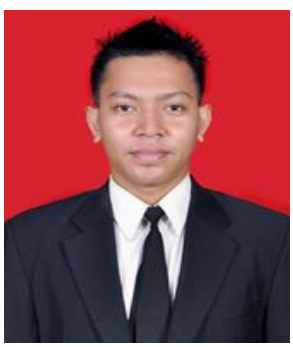

Keywords

accounting quality;

education;

information;

intention;

selecting stock;

\begin{abstract}
The aim of the current study was to examine and to obtain empirical evidence of the behavior of individual investors in the stock investment decisions. It was quantitative research which applied sampling purposive technique for gaining data. The population of this study was individual investors in Jayapura who were actively investing in the Indonesia Stock Exchange. The results have shown that (1) Information quality systems have got significant positive influence towards the intensity of stock selection; (2) Return influences the intensity of stock selection; and (3) Education has no influence towards the intensity of stock selection.
\end{abstract}

e-ISSN: 2550-7001, p-ISSN: 2550-701X ๑ Copyright 2019. The Author. SS Journals Published by Universidad Técnica de Manabí. This is an open-access article under the CC BY-SA 4.0 license (https://creativecommons.org/licenses/by-sa/4.0/) All rights reserved.

\section{Contents}

Abstract 171

1. Introduction 172

2. Materials and Methods 172

2.1 The Effect of the Information Quality Systems on Stock Selection Intensity ........................................... 173

2.2 Effect of Return on Stock Selection Intensity .......................................................................................... 173

2.3 The Effect of Education in Stock Selection Intensity .............................................................................. 174

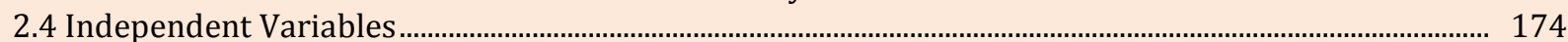

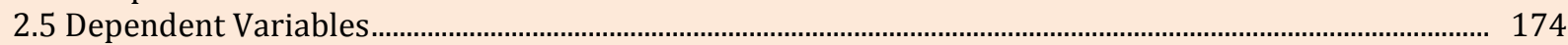

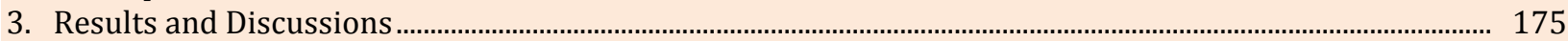

3.1 The Effect of the Information Quality Systems on Stock Selection Intensity (H1) ..................................175

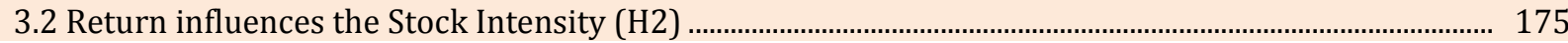

a Universitas Yapis Papua, Indonesia

b Universitas Yapis Papua, Indonesia 
3.3 The Effect of Education in Stock Selection Intensity (H3) ……................................................................ 176

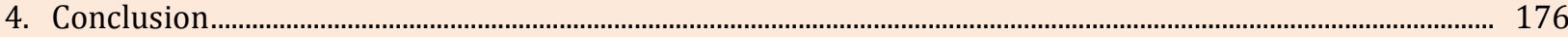

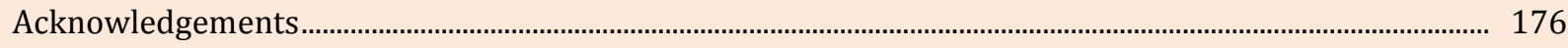

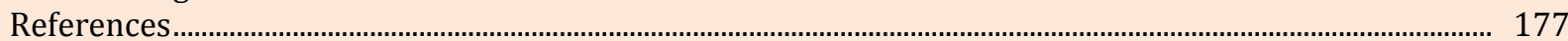

Biography of Authors ............................................................................................................................................... 178

\section{Introduction}

The business world is currently entering the era of digital commerce (Tejeda et al., 2014). This digital "virus" has also penetrated the capital market. Securities transactions involving sheet shares in a trading floor have changed and switched to digital out systems scriptless. The rapid development of the global economy has created qualified information which is valid and in real time (Gereffi, 2005). It has become a major requirement for investors. Stock prices have become more sensitive, even the slightest change in information can affect market psychology (Porter, 2000). Thus, the quality of information systems produced by technology will assist investors in making stock selection decisions through an online trading system (Thimotius, 2016).

The theory of planned behavior (Ajzen, 1988, 1991) has emerged as one of the most influential and popular conceptual frameworks for the study of human action (Ajzen, 2001). Briefly, according to the theory, human behavior is guided by three kinds of considerations: beliefs about the likely consequences or other attributes of the behavior (behavioral beliefs), beliefs about the normative expectations of other people (normative beliefs), and beliefs about the presence of factors that may further or hinder performance of the behavior (control beliefs). However, the intention to invest will not be useful without the existence of supporting facilities such as online trading (Fadhilah, 2017). The facility of online trading helps investors to transact wherever and whenever that is by using devices that can access the internet. This, undeniable, makes investors feel easier to make decisions. In addition, investors can also access financial statements, stock trends, read the news, as well as assess the returns company's stock and risks by using an online trading system (Thimotius, 2016).

In Indonesia, the capital market movement is still very volatile, where the gap between the increase and decrease in the JCI is still very high. This is experienced by many developing countries, including Indonesia. The problem of developing countries, in general, is the gap in the quality of human resources that are still high. Related to this study, the intended human resources are individual investors, so the quality of individual investor behavior in stock investment decision making is very important to understand as a reference for capital market movements (Masrurun, 2015). Therefore, education about the capital market is important for investors since it is useful to increase understanding and knowledge about stock investment. This adequate knowledge will shape one's skills in creating value and profit. Furthermore, it is able to manage risk as well as to reduce the impact of losses that might be experienced by the investors (Riyadi, 2016).

This study aims to examine and to obtain the intensity of young investors in Papua empirically. Young investors are an interesting focus as they belong to the digital generation. Digital generation here means the generation born after 1980. Since basic education has been related to the system of computers, the internet, digital money (credit and debit cards), digital cameras and so on have been something common for the generation (Kasali, 2011). In addition, the unit of analysis of this study is young Papuan investors with the status of university students who are faced as important agents in the development of capital markets in Papua.

\section{Materials and Methods}

\section{Intensity Investors in Stock Selection}

Theory of Planned Behavior (TPB) proposed by Ajzen (1986; 1991), provides a framework for studying attitudes toward behavior. TPB is based on the assumption that humans are rational beings and use information that is possible for them systematically. People think of the implications of their actions before they decide to do or not do certain behaviors (Masrurun, 2015). 
Intention to invest requires specialized analytical knowledge to believe about the performance of shares that will be chosen in the overall stock investment (Hartono, 2007). Intention to invest is a cognitive process to estimate risk and return. This form of attitude is supported by three factors, namely: first, determination: the existence of motivation, intention, and strong goals. Second, self-discipline: knowing what and when to do something. Third, fighting: hard work, smart work, and time management.

\section{Quality of Information System}

The quality of information systems must be relevant, reliable, increase knowledge, and confidence in their use (Scott, 2011). This system was developed from e-commerce technology or internet technology-based business systems. Online trading has become a separate necessity for shareholders. This facility will make it easier for investors to conduct transactions compared to conventional transactions and investors can easily update the company's financial information they want because the data is supported in real time (Wulandari, 2017).

\section{Return}

Return is the result obtained from investment in an investment. Jogiyanto (2010), states that the return can be the realization of returns (Tirrenus return that calculated using historical data) or return expectations (expected return), which has not happened yet but is expected to occur in the future. Returns and risks in investment have a positive relationship, namely the higher the risk, the higher the return the expected. Jogiyanto (2010), states that risk is often associated with deviations or deviations from the outcome received with the expected.

\section{Education}

Related to the current research, adequate knowledge that a person has will increase his confidence. Capital market training held by securities and Investment Gallery in higher education will increase students' understanding and awareness of the importance of investing, how to invest and all things that should be known to prospective investors, including to avoid fictitious investments (Tandio \& Widanaputra, 2016).

\section{Hypothesis Development}

\subsection{The Effect of the Information Quality Systems on Stock Selection Intensity}

Technology is expected to be able to make investors more interested in conducting stock transactions. Investors can access capital market information at any time using an online trading system with an internet connection. The need for speed and accuracy in stock exchange transactions is very important so as to facilitate various parties related, especially investors, to be able to quickly analyze and make decisions (Tandio \& Widanaputra, 2016). Research results from Masrurun (2015); Irvan (2017); Septyanto et al., (2013), revealed that the quality of financial information systems has a positive effect on the intensity of investor stock selection. According to Masrurun (2015), qualified information systems show that companies have sound financial. As the implication, this will be a belief for investors to choose stocks that provide quality information systems. Based on this description, the hypothesis in this study was (H1) the quality of information systems influences the intensity of stock selection.

\subsection{Effect of Return on Stock Selection Intensity}

The theory of return of investment and risk states that the greater the return that might be obtained, the greater the investor's interest in investing (Hartono, 2010). One object that becomes the target of investor investment is, of course, an advantage, which in this case means to gain or return. However, Riyadi's (2016), research results state that returns have not been able to prove its influence on interest in investing in the capital market. Because the average prospective investor before investing very pay attention to the risks that

$$
\begin{array}{r}
\text { Seralurin, Y. C., \& Yendra, -. (2019). The intensity of stock selection: A case of young Papuan investors. } \\
\text { International Journal of Social Sciences and Humanities, 3(1), } 171-178 . \\
\text { https://doi.org/10.29332/ijssh.v3n1.262 }
\end{array}
$$


exist compared to returns that will be accepted. Returns Stock can be positive and also negative. Positive means investors get profit (capital gain), while negative means investors suffer losses (capital lost). Unlike Tandio \& Widanaputra (2016), which states that returns have a significant effect on the intensity of stock selection. Prediction or prediction of return (return expectation) in the future is information that affects the desire of investors to invest, especially if the investment risk is high enough, of course, investors expect high returns as well. Based on this description, the hypothesis in this study was (H2) Return influences the stock intensity.

\subsection{The Effect of Education in Stock Selection Intensity}

When investing in the capital market, sufficient knowledge is needed through the capital market school to analyze which effects will be purchased, then investors will be intense for stock selection. The research finding of Tandio \& Widanaputra (2016), state that education influences students' interest in investing. Lipsey \& Sjöholm (2004), explained that education about investment is absolutely necessary for a prospective investor before making a stock selection. But it is different from the results of research conducted by Riyadi (2016), which states that education does not affect student interest in the intensity of investing. This is because prospective investors feel that education or socialization of investment in the capital market is less attractive. In conducting socialization, capital market and securities parties should be more innovative so that potential investors are interested in investing in the capital market. Based on this description, the hypothesis in this study was (H3) Education influences the intensity of stock selection.

In order to examine the problems in the current research, we conducted research by applying a quantitative approach. Sources of data in this study were obtained through questionnaires. The population in this study were native Papuan students who actively transacted shares in the Jayapura region. The sample was native Papuan students at several private universities in Jayapura, namely UNIYAP, USTJ, STIE OTTOW GEISSLER, STIE PORT NUMBAY. The sample selection criteria were as follows: (a) Papuan native students who are active in buying and selling shares, (b) Papuan native students who have at least three months of stock transaction experience, and (c) Papuan native students who have taken the education process. Next, the independent variables and the dependent variable of the current research are presented as follows.

\subsection{Independent Variables}

\section{a) Quality Information System}

Quality Accounting Information System is the respondent's perception of the availability of information technology facilities such as online trading which makes it easy to update information and confidence in choosing stocks that generate returns. The instrument for measuring system quality information was taken from the research of Masrurun (2015).

\section{b) Return}

Return investment is the respondent's perception of the benefits provided by capital market instruments in the form of dividends and capital gains. The measuring instrument of returned investment was taken from the research of Riyadi (2016).

\section{c) Education}

Investment education is a perception of knowledge that has been given both to students given by the university or from external parties regarding investment in the capital market (Hermanto, 2017). An instrument for measuring investment education was taken from Riyadi (2016).

\subsection{Dependent Variables}

The dependent variable of the current research was the Intensity of Stock Selection. The intensity of stock selection itself is the intention to choose candidate shares that are determined directly from the securities analyst's confidence in the estimation of returns and risks stock. In the current research, the instrument for measuring intensity in stock elections was taken from the research of Masrurun (2015). The measurement of 
the answers to the statement items was submitted using the Likert 5 scale that revolved around "strongly disagree" to "strongly agree".

This study used a multiple linear regression test to measure the relationship between each independent variable with the dependent variable. The three activities were conducted simultaneously, namely examination of validity tests, classic assumption tests, hypothesis testing. Following is the figure of the research framework.

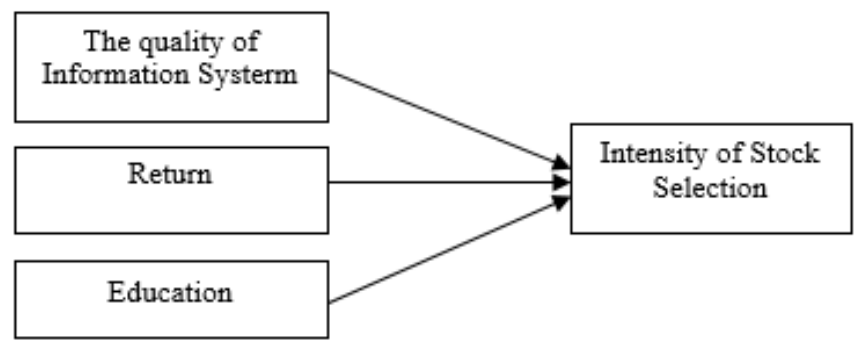

Figure 1. Research Framework

\section{Results and Discussions}

As have been stated, this study used data obtained by surveying and distributing questionnaires to respondents. The questionnaire was distributed to meet the criteria as samples. The population in this study were Papuan Native Students who actively transacted shares in the Jayapura region.

Table 1

Distribution and return of questionnaires

\begin{tabular}{lc}
\hline \multicolumn{1}{c}{ Questionnaire } & Total \\
\hline Distributed questionnaire & 80 \\
The returned questionnaire & 75 \\
The unreturned questionnaire & 5 \\
The incomplete questionnaire & 8 \\
The processed questionnaire & 63 \\
Rate of Responses & 78,75 \\
\hline
\end{tabular}

\subsection{The Effect of the Information Quality Systems on Stock Selection Intensity (H1)}

Based on the results of calculations for the first hypothesis, namely the Information System Quality variable (X1), it is obtained that the value of $t$ arithmetic is 5.687, with a significance level of 0.000 is smaller than $\alpha=0.05$. In other words, it is stated that $0.000>0.05$. It means H1 is accepted. X1 has a significant effect in a positive direction towards Stock Selection Intensity (Y) for Papuan Native Investors. The results of this study support previous researches conducted by Masrurun (2015) and Arrozi (2014). They have found that the quality of information systems influences the intensity of investor stock selection. Masrurun (2015), states that the more quality information systems, the more investors believe to trade. When investors believe more, they will be more intense in trading. Through information system of online trading data which is acquired in real time, the investors are helped to obtain information effectively. It increases the intensity of stock selection. 
3.2 Return influences the Stock Intensity (H2)

Based on the results of calculations for the second hypothesis, namely, Return variable (X2), it is obtained that $t$ count, that is 1.356 , with a significance level of 0.018 is smaller than $\alpha=0.05$. In other words, it is stated that $0.018<0.05$. Thus, $\mathrm{H} 2$ is accepted, which means that partially the Educational variable (X2) has a significant effect on the positive direction of Stock Intensity (Y) on Papuan Native Students. The results of this study reject the research conducted by Riyadi (2016), who argues that the average prospective investor prior to investing is very concerned about the risks that exist, compared to the return to be received. Research conducted by Tandio \& Widanaputra (2016), states that predictions of future returns (return expectations) are information that affects investors' desire to invest, especially if the investment risk is high enough, of course, investors expect high returns also. Based on the finding of the current research, the statement of Tandio \& Widanaputra (2016), is rejected.

\subsection{The Effect of Education in Stock Selection Intensity (H3)}

Based on the results of calculations for the third hypothesis, namely the Education variable (X2), it is obtained that $t$ count, 2.425 , with a significance level of 0.180 , is greater than $\alpha=0.05$. In other words, $0.180>$ 0.05 . Based on the calculation, H3 is rejected. It means that the variable education partially (X2) does not affect the Stock Intensity (Y) on Papuan investors. The results of this study support the research conducted by Riyadi (2016), that education or socialization of investment in the capital market is less attractive to prospective investors. In the other side, the current result rejects the research conducted by Lipsey \& Sjöholm (2004). Lipsey \& Sjöholm (2004), state that knowledge or education about investment is absolutely necessary for a prospective investor before plunging into the world of capital markets or business.

\section{Conclusion}

Based on the previous section about the analysis and discussion of the current study results, it is concluded that (1) Information Quality Systems has got significant positive influence towards the intensity of stock selection; (2) Return influences the intensity of stock selection, (3) education has no influence towards intensity of stock selection.

Having analyzed on the findings and conclusion of the current research, we suggest some important that can be given are, (1) For further research it is recommended to use a larger sample so that the results will be more convincing. (2) The results of the study have shown that native Papuan investors who are currently university students are good enough in using technology applications of online trading. Despite the high cost of internet packages and limited network access, they have the passion and a strong desire to know more about the capital market.

\section{Acknowledgments}

The authors would like to acknowledge the editor of IJSSH for their valuable time, support and advice to complete the present study. This work was supported by the independent research fund. 


\section{References}

Ajzen, I. (1988). Attitudes, personalia, and behavior. Chicago, IL: Dorsey.

Ajzen, I. (1991). The theory of planned behavior. Organizational behavior and human decision processes, 50(2), 179-211. https://doi.org/10.1016/0749-5978(91)90020-T

Ajzen, I. (2001). Nature and operation of attitudes. Annual review of psychology,52(1), 27-58. https://doi.org/10.1146/annurev.psych.52.1.27

Ajzen, I., \& Fishbein, M. (1988). Theory of reasoned action-Theory of planned behavior. University of South Florida, 2007, 67-98.

Anggraiawan, I., Isynuwardhana, D., \& Mahardika, D. (2017). Determinan Perilaku Investor Individu Dalam Pengambilan Keputusan Investasi Saham Pada Investor Yang Terdaftar Di Gi-bei Telkom University. eProceedings of Management, 4(1).

FADHILAH, M. (2017). Analisis faktor-faktor yang mempengaruhi minat mahasiswa untuk berinvestasi di pasar modal (studi pada mahasiswa fakultas ekonomi universitas negeri jakarta) (Doctoral dissertation, Fakultas Ekonomi).

Gereffi, G. (2005). The global economy: organization, governance, and development. The handbook of economic sociology, 2, 160-182.

Hermanto, H. (2017). Perilaku Mahasiswa Ekonomi di Universitas Esa Unggul dalam Melakukan Investasi di Pasar Modal. Jurnal Ekonomi Universitas Esa Unggul, 8(01).

Jogiyanto, H. (2010). Teori Portofolio dan Analisis Investasi. Edisi Ketujuh. Yogyakarta: BPFE.

Jogiyanto, H. (2010). Teori Portofolio dan Analisis Investasi. Edisi Ketujuh. Yogyakarta: BPFE.

Lipsey, R. E., \& Sjöholm, F. (2004). Foreign direct investment, education and wages in Indonesian manufacturing. Journal of Development $\quad$ Economics, 73(1), https://doi.org/10.1016/j.jdeveco.2002.12.004

Masrurun, I. (2015). Determinan perilaku investor individu dalam pengambilan keputusan investasi saham (Studi pada Mahasiswa Anggota KSPM di Semarang)(Doctoral dissertation, Universitas Negeri Semarang).

Porter, M. E. (2000). Location, competition, and economic development: Local clusters in a global economy. Economic development quarterly, 14(1), 15-34. https://doi.org/10.1177/089124240001400105

Scott, W. (2011). R. 2003. Financial accounting theory, 3. https://www.amazon.com/Financial-AccountingTheory-William-Scott/dp/0135119154

Septyanto, D., \& Adhikara, M. A. (2013). Perilaku Investor Individu Dalam Pengambilan Keputusan Investasi Sekuritas Di Bursa Efek Indonesia (Bei). Sustainable Competitive Advantage (SCA), 3(1).

Tandio, T., \& Widanaputra, A. G. (2016). Pengaruh Pelatihan Pasar Modal, Return, Persepsi Risiko, Gender, Dan Kemajuan Teknologi Pada Minat Investasi Mahasiswa. E-Jurnal Akuntansi, 2316-2341.

Tejeda-Lorente, Á., Porcel, C., Peis, E., Sanz, R., \& Herrera-Viedma, E. (2014). A quality based recommender system to disseminate information in a university digital library. Information Sciences, 261, 52-69.

Tejeda-Lorente, Á., Porcel, C., Peis, E., Sanz, R., \& Herrera-Viedma, E. (2014). A quality based recommender system to disseminate information in a university digital library. Information Sciences, 261, 52-69. https://doi.org/10.1016/j.ins.2013.10.036

Wulandari, P. A., Sinarwati, N. K., \& Purnamawati, I. G. A. (2017). Pengaruh Manfaat, Fasilitas, Persepsi Kemudahan, Modal, Return, dan Persepsi Risiko Terhadap Minat Mahasiswa untuk Berinvestasi Secara Online (Studi pada Mahasiswa Jurusan Akuntansi Program S1 Universitas Pendidikan Ganesha). JIMAT (Jurnal Ilmiah Mahasiswa Akuntansi) Undiksha, 8(2). 


\section{Biography of Authors}

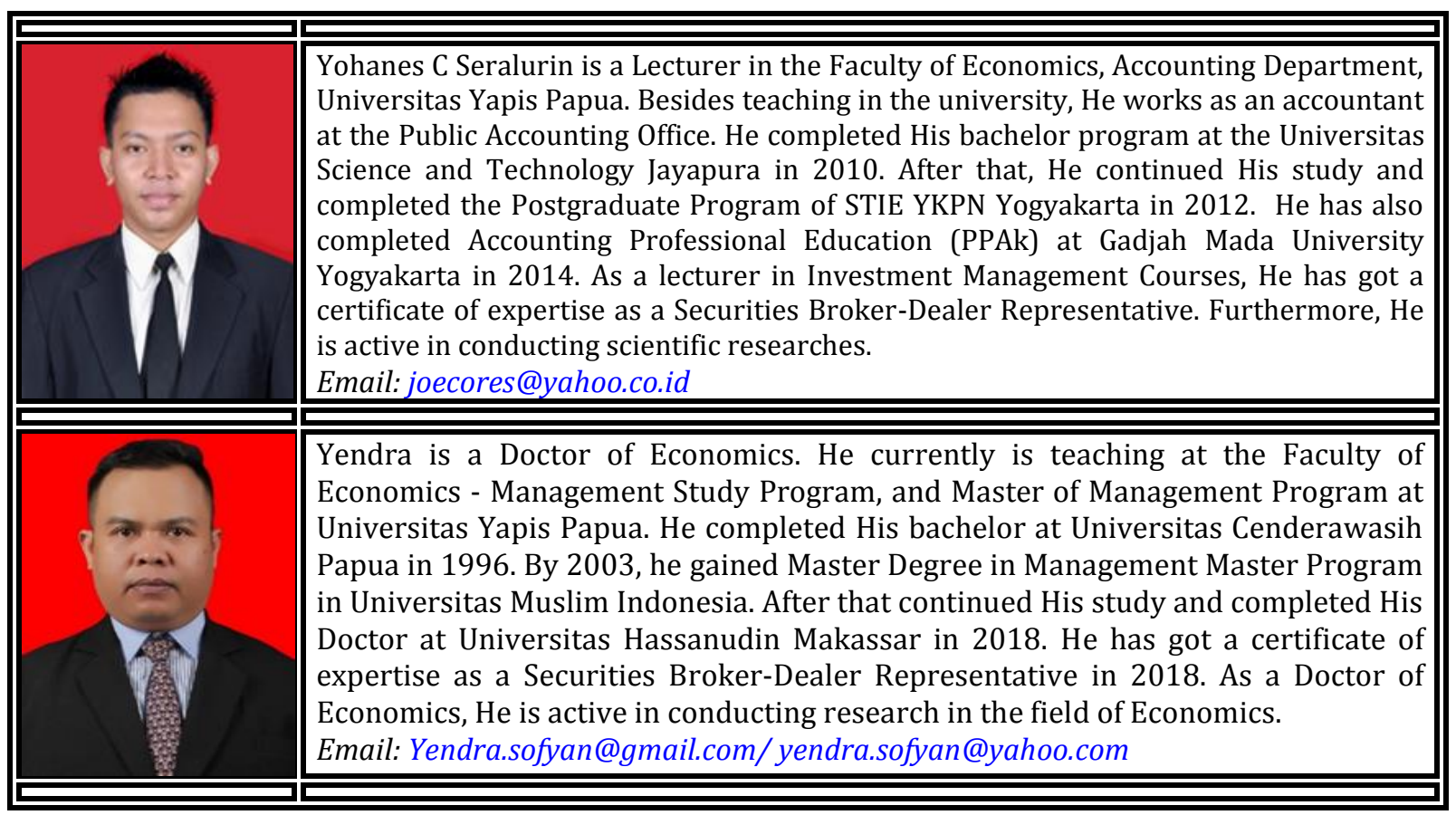

